\title{
Pengaruh Lingkungan Sosial Terhadap Kinerja Penyuluh Keluarga Berencana Kota Palembang dan Kota Prabumulih
}

\section{The Influence of Social Environment on the Family Planning Counselor Performance in Palembang and Prabumulih City}

\author{
Lausa Isaberna1)*, Sriati2) \& Dadang Hikmah Purnama3) \\ 1)Magister Sosiologi, Fakultas Ilmu sosial dan Politik, Universitas Sriwijaya, Indonesia \\ 2) Fakultas Pertanian, Universitas Sriwijaya, Indonesia \\ 3) Fakultas Ilmu Sosial dan Politik, Universitas Sriwijaya, Indonesia \\ Diterima: 19 Mei 2021 Direview: 19 Mei 2021; Disetujui: 06 Agustus 2021 \\ *Coresponding Email: lausa.isaberna@gmail.com
}

\begin{abstract}
Abstrak
Dalam menjalankan Perannya sebagai Penyuluh KB (Keluarga Berencana), tugas dan fungsi Penyuluh KB juga dipengaruhi oleh orang-orang disekitar yang dapat mendukung kinerja dan menghambat kinerja. Penyuluh KB lebih sering berinteraksi dengan masyarakat sebagai sasaran program baik langsung maupun tidak langsung. Penelitian ini dimaksud untuk melihat seberapa besar pengaruh Lingkungan Sosial terhadap Kinerja Penyuluh KB. Metode penelitian yang digunakan adalah kuantitatif. Pengumpulan data dilakukan dengan kuisioner yang telah diuji validitas dan reabilitasnya. Populasi dalam penelitian ini adalah Penyuluh KB Kota Palembang dan Prabumulih dengan sampel sebanyak 30 orang dan diambil dengan teknik Puposive sampling. Hasil Penelitian ini menunjukan bahwa lingkungan sosial mempengaruhi kinerja penyuluh secara siginifikan dan positif sebesar 75 persen, Artinya semakin baik lingkungan sosial semakin baik pula kinerja Penyuluh KB.
\end{abstract}

Kata Kunci: Lingkungan Sosial, Kinerja Penyuluh Keluarga Berencana

\begin{abstract}
In carrying out its role as a family planning instructor, the duties and functions of family planning instructors are also influenced by the people around them who can support their performance and hinder their performance. Family planning extension workers often interact with the community as program targets, either directly or indirectly. This research is intended to see how much influence the social environment has on the performance of family planning instructors. The research method used is quantitative. The data was collected using a questionnaire that had been tested for its validity and reliability. The population in this study were the Palembang and Prabumulih family planning instructors with a sample of 30 people and were taken using a purposive sampling technique. The results of this study indicate that the social environment has a significant and positive influence on the performance of the extension workers by 75 percent. This means that the better the social environment, the better the performance of the family planning instructors.

Keywords: Social Environment; Family Planning Instructor Performance

How to Cite: Isaberna, L. Sriati. \& Purnama, D.H. (2021). Pengaruh Lingkungan Sosial Terhadap Kinerja Penyuluh Keluarga Berencana Kota Palembang dan Kota Prabumulih, Journal of Education, Humaniora and Social Sciences (JEHSS). 4 (2): 695-701.
\end{abstract}




\section{PENDAHULUAN}

Gambaran capaian program kependudukan keluarga berencana dan pembangunana Keluarga (KKBPK) dapat dilihat dari data keterpajanan wanita Usia subur dalam memperoleh informasi tentang keluarga berencana. Berdasarkan data survei Demografi dan Kesehanat Indonesia (SDKI) tahun 2017 diperolah data bahwa wanita umur 15-49 memperoleh informasi tentang Keluarga Berencana (KB) sebagian besar dari Perawat atau Bidan yaitu sebesar 23 persen, sedangkan dari pertugas KB hanya 5 persen. Padahal Kegiatan Non Medis yaitu penyuluhan KB merupakan tugas dan fungsi Penyuluh KB sebagai petugas lini lapangan program. Kondisi ini mengasumsikan bahwa kinerja Penyuluh KB dalam keadaan yang relatif rendah. Kinerja sangat berkaiatan dengan bagaimana seseorang memainkan peranannya.

Mangkunegara (2016), mendefinisikan kinerja adalah apa yang dapat dikerjakan seseorang sesuai dengan tugas dan fungsinya. Dari batasan-batasan yang ada dapat dirumuskan bahwa kinerja (performance) adalah hasil kerja yang dapat ditampilkan atau penampilan kerja seorang karyawan. Harsuko (2011), berpendapat bahwa kinerja adalah sejauh mana seseorang telah memainkan bagiannya dalam melaksanakan strategi organisasi, baik dalam mencapai sasaran khusus yang berhubungan dengan peran perorangan dan atau dengan memperlihatkan kompetensi yang dinyatakan relevan bagi organisasi. Dengan demikian kinerja seorang karyawan dapat diukur dari hasil kerja, hasil tugas, atau hasil kegiatan dalam kurun waktu tertentu.

Kinerja seorang karyawan dalam suatu organisasi atau institusi kerja, dipengaruhi oleh banyak faktor, baik faktor dari dalam karyawan itu sendiri maupun faktor lingkungan atau organisasi kerja itu sendiri. Menurut Nitisemito (2002), lingkungan kerja dalah segala sesuatu yang ada di sekitar para pekerja dan yang dapat mempengaruhi dirinya dalam menjalankan tugastugas yang dibebankannya. Menurut Ainsworth et al (2002), Lingkungan dapat digolongkan dalam lingkungan fisik, lingkungan sosial, dan lingkungan organisasi dan lingkungan bukan pekerjaan.

Dalam menjalankan tugas dan fungsi Penyuluh KB dipengaruhi oleh orang-orang disekitar penyuluh KB yang dapat menunjang dan mendukung kinerja dan juga dapat menghambat atau melemahkan kinerja. Sebagai petugas lapangan, Penyuluh KB lebih sering berinteraksi pada masyarakat sebagai sasaran program baik langsung maupun tidak langsung. Lingkungan kerja penyuluh KB yang berbeda dengan lingkungan pekerja pada umumnya. Penyuluh KB tidak memiliki ruangan khusus untuk bekerja. Penyuluh KB menjalankan tugas dan fungsinya langsung kepada masyarakata sebagai sasaran program. Sehingga dukungan dari masyarakat menjadi salah satu faktor keberhasilan penyuluhan.

Penelitian sebelumnya mengenai lingkungan kerja dan Penyuluh KB sudah pernah dilakukan, salah satunya adalah penelitian Darmanto (2016), yang mengemukakan bahwa jika lingkungan di sekitar penyuluh semakin baik maka akan meningkatakan kinerja Penyuluh sebaliknya jika lingkungan disekitar penyuluh buruk maka akan menurunkan kinerja penyuluh. Rusmiah et al., (2019), juga mengungkapan bahwa lingkungan kerja secara simulthan mempengaruhi kinerja penyuluh. Penelitian milik Darmanto (2016) dan Rusmiah et al., (2019) sama-sama mengungkapkan bahwa lingkungan akan mempengaruhi kinerja Penyuluh KB. Namun konsep lingkungan yang diteliti sebagian besar mengarah pada lingkungan fisik sarana dan parasarana di dalam ruangan saja, seperti ATK dan balai Penyuluhan, padahal penyuluh KB lebih banyak melakukan aktifitas kerja diluar ruangan kerja dan langsung menemui masyarakat wilayah binaan sebagai sasaran program dan mitra kerja.

Hal ini menjadi menarik untuk dikaji lebih lanjut pengaruh lingkungan sosial karena kinerja penyuluh KB yang berbeda dengan kinerja karyawan umumnya. Beberapa penelitian, meneliti Kinerja Pegawai dari sudut pandang manjemen organisasi, yaitu memandang lingkungan dari sudat fisik dan non fisik saja. Penelitian ini menggunakan konsep lingkungan kerja dalam sudut pandang sosiologi. Lingkungan kerja yang dimaksud dalam penelitian ini adalah lingkungan sosial berupa interkasi penyuluh KB dengan masyarakat sebagai sasaran dan masyarakat sebagai mitra kerja. Menurut Sedarmayanti (2009), lingkungan sosial adalah semua kondisi yang terhadi dan berkaitan dnegan hubungan kerja. Penelitian ini bertujuan untuk melihat seberapa besar pengaruh lingkungan sosial yang dijabarkan dimensi dukungan masyarakat sebagai sasaran 
program dan masyarakat sebagai mitra kerja terhadap kinerja Penyuluh KB Kota Palembang dan Kota prabumulih dalam dimensi pemahaman terhadap tupoksi, Inovasi, keakuratan kerja, kecepatan kerja dan kerjasama.

\section{METODE PENELITIAN}

Penelitian ini menggunakan penelitian kuantitatif yang dilakukan di Kota Palembang dan Kota Prabumulih. Pendekatan yang digunakan dalam penelitian ini adalah pendekatan explanotory Survei yang bertujuan untuk menjelaskan hubungan dua variabel atau lebih (Singarimbun, 1995). Populasi dalam penelitian ini adalah semua Penyuluh KB kota Palembang dan Kota Prabumulih yang berjumlah 65 orang. Peneliti menggunakan Penyuluh KB kta palembang dan Prabumulih atas pertimbangan rasio ideal jumlah penyuluh dengan wilayah binaan. Penyuluh KB kota palembang dan prabumulih jika di bandingkan dengan wilayah lain memiliki rasio yang memadai. Pengambilan sampel dilakukan dengan teknis proposive sampling. Sampel dalam penelitian ini adalah Penyuluh KB kota pelembang dan kota prabumulih sebanyak 30 orang. Dasar pengambilan Sampel dengan jumah 30 orang adalah jumlah batas minimal yang harus diambil oleh peneliti yaitu sebanyak 30 sampel (Cohen et al., 2007)

Pengumpulan data dilakukan dengan kuisioner yang sudah dilakukan uji validasi dan reabilitas. Teknik analisis menggunakan analisis regresi Liner sederhana.

\section{HASIL DAN PEMBAHASAN}

\section{Tingkat Lingkungan Sosial Penyuluh KB}

Lingkungan sosial merupakan segala sesuatu bukan peralatan yang berada disekitar pekerja. Lingkungan sosial diartikan sebagai manusia yang berada di sekitaran pekerja. Dalam penelitian ini lingkungan sosial penyuluh KB merupakan masyarakat sebagai sasaran dan masyarakat sebagai mitra kerja yang berada di sekitar penyuluh KB yang dapat mendukung atau menghambat kinerja penyuluh KB. Untuk mendapatkan gamabran mengenai tingkat lingkungan sosial Penyuluh KB dengan dimensi dukungan dari masyarakat sebagai sasaran program dan dukungan masyarakat sebagai mitra kerja peneliti memberikan skor pada tiap jawaban yang diberikan responden sesuai pilihan skala linket 1-5. Berikut ini adalah gabaran tingkat lingkungan sosial Penyuluh KB kota Palembang dan Kota Prabumulih

Tabel. 1 Deskripsi Skor Jawaban Variabel Lingkungan Sosial penyuluh KB

\begin{tabular}{|c|c|c|c|c|c|c|c|c|c|}
\hline \multirow{2}{*}{ item } & \multicolumn{5}{|c|}{ Distribusi Jawaban } & \multirow{2}{*}{$\begin{array}{l}\text { Skor } \\
\text { Total }\end{array}$} & \multirow{2}{*}{$\begin{array}{c}\text { Rata- } \\
\text { rata }\end{array}$} & \multirow{2}{*}{ Capaian } & \multirow{2}{*}{$\begin{array}{l}\text { Kriteria } \\
\text { capaian }\end{array}$} \\
\hline & STS & TS & $\mathrm{CS}$ & $\mathbf{S}$ & SS & & & & \\
\hline 1 & 1 & 2 & 6 & 8 & 13 & 120 & 4,0 & $80 \%$ & Tinggi \\
\hline 2 & 0 & 1 & 5 & 12 & 12 & 125 & 4,2 & $83 \%$ & Tinggi \\
\hline 3 & 0 & 1 & 8 & 10 & 10 & 116 & 3,9 & $77 \%$ & Tinggi \\
\hline 4 & 0 & 2 & 10 & 11 & 7 & 113 & 3,8 & $75 \%$ & Tinggi \\
\hline 5 & 0 & 2 & 10 & 11 & 7 & 113 & 3,8 & $75 \%$ & Tinggi \\
\hline 6 & 0 & 0 & 11 & 8 & 11 & 120 & 4,0 & $80 \%$ & Tinggi \\
\hline 7 & 0 & 2 & 11 & 9 & 8 & 113 & 3,8 & $75 \%$ & Tinggi \\
\hline 8 & 0 & 1 & 8 & 11 & 10 & 120 & 4,0 & $80 \%$ & Tinggi \\
\hline 9 & 0 & 5 & 7 & 9 & 9 & 112 & 3,7 & $75 \%$ & Tinggi \\
\hline 10 & 0 & 1 & 8 & 10 & 11 & 121 & 4,0 & $81 \%$ & Tinggi \\
\hline 11 & 0 & 5 & 7 & 6 & 12 & 115 & 3,8 & $77 \%$ & Tinggi \\
\hline 12 & 0 & 2 & 8 & 9 & 11 & 119 & 4,0 & $79 \%$ & Tinggi \\
\hline 13 & 0 & 1 & 10 & 6 & 13 & 121 & 4,0 & $81 \%$ & Tinggi \\
\hline 14 & 0 & 2 & 11 & 10 & 7 & 112 & 3,7 & $75 \%$ & Tinggi \\
\hline 15 & 0 & 0 & 8 & 7 & 15 & 127 & 4,2 & $85 \%$ & Sangat Tinggi \\
\hline 16 & 0 & 1 & 10 & 9 & 10 & 118 & 3,9 & $79 \%$ & Tinggi \\
\hline
\end{tabular}




\begin{tabular}{|c|c|c|c|c|c|c|c|c|c|}
\hline \multirow{2}{*}{ item } & \multicolumn{5}{|c|}{ Distribusi Jawaban } & \multirow{2}{*}{$\begin{array}{l}\text { Skor } \\
\text { Total }\end{array}$} & \multirow{2}{*}{$\begin{array}{c}\text { Rata- } \\
\text { rata }\end{array}$} & \multirow{2}{*}{ Capaian } & \multirow{2}{*}{$\begin{array}{l}\text { Kriteria } \\
\text { capaian }\end{array}$} \\
\hline & STS & TS & CS & $S$ & SS & & & & \\
\hline 17 & 1 & 2 & 9 & 11 & 7 & 111 & 3,7 & $74 \%$ & Tinggi \\
\hline 18 & 2 & 4 & 5 & 9 & 10 & 111 & 3,7 & $74 \%$ & Tinggi \\
\hline Total & 4 & 34 & 152 & 166 & 183 & 2107 & 70,2 & $78 \%$ & Tinggi \\
\hline
\end{tabular}

Sumber : Diolah dari data primer (2021)

Berdasarkan pengukuran tingkat lingkungan sosial dimana indikator pengukuran adalah dukungan masyarakat sebagai sasaran program dan dukungan masyarakat sebagai mitra kerja diperoleh angka yang menunjukan bahwa capaian berada dalam katagori tinggi. Capaian yang skro dalam katagori tinggi menunjukan bahwa kondisi lingkungan sosial dalam keadaan baik. Hubungan Penyuluh KB kota palembang dan Kota Prabumulih dengan lingkungan manusia disekitarnya dalam kondisi yang baik. Hal ini ditunjukan dengan dukungan masyarakat yang menerima dan mendukung kegiatan-kegiatan penyuluh KB dalam menjalankan programnya. Pasangan usia subur sebagai sasaran program KB mendukung kegiatan yang dilakukan penyuluh KB dan juga mendukung pribadi penyuluh sebagai seseorang yang menjalankan program Keluarga Berencana. Keluarga yang memiliki balita, remaja dan lansia sebagai sasaran pembangunan keluarga juga mendukung kegiatan yang dilakukan penyuluh dan mendukung probadi penyuluh sebagai seorang yang menjalankan program pembangunan keluarga. Hal ini mendukung penelitian yang dilakukan oleh Puspita (2011), yang mengatakan bahwa hubungan sosial antara penyuluh dengan orang disekitarnya utamanya dukungan dari masyarakat akan memberikan dampak pada tindakan yang dilakukan oleh penyuluh KB. Lingkungan sosial yang baik akan menjadikan proses interaksi sosial lebih terasa nyaman. Lingkungan sosial penyuluh KB memiliki peranan yang besar dalam proses kerja penyuluh karena penyuluh melakukan tugas dan fungsinya langsung berkenaan pada masyarakat sebagai sasaran program dan mitra kerja. Penelitian lain yang juga sejalan adalah penelitian dari Rusmiah et al (2019), yang mengatakan bahwa dukungan dari lingkungan sosial melalui interaksi dengan masyarakat akan memudahkan pelaksanaan pekerjaan.

\section{Tingkat Kinerja Penyuluh KB}

Kinerja penyuluh KB diartikan sebagai pernan penyuluh KB dalam mencapai sebuah target program. Kinerja Penyuluh KB dapat dilihat dengan sejauh mana Penyuluh Kb melaksanakan tugas dan fungsinya untuk mencapai program kependudukan, keluarga berencana dan pembangunan keluarga. Peranan penyuluh KB sebagai tenaga lini lapangan bertujuan untuk mencapai program kependudukan, keluarga berencana dan pembangunan keluarga di wilayah binaannya yaitu pada tataran tingkat desa. Di sampaikan oleh Syafruddin et al (2014),bahwa seorang penyuluh dapat dikatakan memiliki kinerja yang baik jika mampu membuktikan capaian indikator ukuran yang menuju pada capaian organisasi. Berikut ini ditampilkan pada Tabel 2, gambaran tingkat kinerja Penyuluh KB kota Palembang dan Prabumulih dalam lima indikator yaitu pemahaman terhadap tugas dan fungsi, inovasi, kecepatan kerja, keakuratan kerja, dan kerja sama.

Tabel 2. Deskripsi Skor Jawaban Variabel Kinerja Penyuluh KB

\begin{tabular}{cccccccccc}
\hline \multirow{2}{*}{ Item } & \multicolumn{4}{c}{ Distribusi Jawaban } & $\begin{array}{c}\text { Skor } \\
\text { Total }\end{array}$ & $\begin{array}{c}\text { Rata- } \\
\text { rata }\end{array}$ & Capaian & $\begin{array}{c}\text { Kriteria } \\
\text { capaian }\end{array}$ \\
\cline { 2 - 5 } & STS & TS & CS & S & SS & & codang \\
2 & 1 & 5 & 9 & 15 & 0 & 98 & 3,3 & $65 \%$ & Sedang \\
3 & 0 & 2 & 8 & 9 & 11 & 119 & 4,0 & $79 \%$ & Tinggi \\
4 & 1 & 2 & 7 & 7 & 13 & 119 & 4,0 & $79 \%$ & Tinggi \\
5 & 0 & 1 & 5 & 12 & 12 & 125 & 4,2 & $83 \%$ & Tinggi \\
6 & 0 & 4 & 9 & 7 & 10 & 113 & 3,8 & $75 \%$ & Tinggi \\
7 & 0 & 3 & 9 & 10 & 8 & 113 & 3,8 & $75 \%$ & Tinggi \\
& 0 & 2 & 10 & 7 & 11 & 117 & 3,9 & $78 \%$ & Tinggi
\end{tabular}


Vol 4, No. 2, November 2021: 695-701

\begin{tabular}{|c|c|c|c|c|c|c|c|c|c|}
\hline \multirow{2}{*}{ Item } & \multicolumn{5}{|c|}{ Distribusi Jawaban } & \multirow{2}{*}{$\begin{array}{l}\text { Skor } \\
\text { Total }\end{array}$} & \multirow{2}{*}{$\begin{array}{l}\text { Rata- } \\
\text { rata }\end{array}$} & \multirow{2}{*}{ Capaian } & \multirow{2}{*}{$\begin{array}{l}\text { Kriteria } \\
\text { capaian }\end{array}$} \\
\hline & STS & TS & CS & $S$ & SS & & & & \\
\hline 8 & 0 & 2 & 7 & 10 & 11 & 120 & 4,0 & $80 \%$ & Tinggi \\
\hline 9 & 0 & 2 & 7 & 10 & 11 & 120 & 4,0 & $80 \%$ & Tinggi \\
\hline 10 & 0 & 2 & 13 & 12 & 3 & 106 & 3,5 & $71 \%$ & Tinggi \\
\hline 11 & 2 & 2 & 8 & 12 & 6 & 108 & 3,6 & $72 \%$ & Tinggi \\
\hline 12 & 0 & 2 & 11 & 9 & 8 & 113 & 3,8 & $75 \%$ & Tinggi \\
\hline 13 & 0 & 4 & 13 & 13 & 0 & 99 & 3,3 & $66 \%$ & Sedang \\
\hline 14 & 0 & 5 & 11 & 13 & 1 & 100 & 3,3 & $67 \%$ & Sedang \\
\hline 15 & 5 & 2 & 18 & 5 & 0 & 83 & 2,8 & $55 \%$ & Sedang \\
\hline 16 & 0 & 5 & 7 & 6 & 12 & 115 & 3,8 & $77 \%$ & Tinggi \\
\hline 17 & 0 & 1 & 8 & 6 & 15 & 125 & 4,2 & $83 \%$ & Tinggi \\
\hline 18 & 1 & 10 & 10 & 9 & 0 & 87 & 2,9 & $58 \%$ & Sedang \\
\hline 19 & 0 & 1 & 8 & 11 & 10 & 120 & 4,0 & $80 \%$ & Tinggi \\
\hline 20 & 1 & 3 & 14 & 11 & 1 & 98 & 3,3 & $65 \%$ & Sedang \\
\hline 21 & 5 & 3 & 11 & 11 & 0 & 88 & 2,9 & $59 \%$ & Sedang \\
\hline 22 & 0 & 2 & 11 & 10 & 7 & 112 & 3,7 & $75 \%$ & Tinggi \\
\hline 23 & 0 & 1 & 11 & 4 & 14 & 121 & 4,0 & $81 \%$ & Tinggi \\
\hline 24 & 0 & 2 & 9 & 9 & 10 & 117 & 3,9 & $78 \%$ & Tinggi \\
\hline 25 & 1 & 2 & 11 & 10 & 6 & 108 & 3,6 & $72 \%$ & Tinggi \\
\hline 26 & 2 & 4 & 5 & 9 & 10 & 111 & 3,7 & $74 \%$ & Tinggi \\
\hline Total & 19 & 74 & 250 & 247 & 190 & 2855 & 95,2 & $73 \%$ & Tinggi \\
\hline
\end{tabular}

Sumber : Diolah dari data Primer (2021)

Berdasarkan pengukuran pada item pertanyaan variabel kinerja diperoleh capaian yang menunjukan katagori tinggi. Hal ini dapat diartikan bahwa kinerja Penyuluh KB kota Palembang dan Kota Prabumulih tergolong dalam kinerja yang baik. Namun jika dilihat lebih jauh pada tiap item pertanyaan beberapa pertanyaan berada dalam katagori sedang yang menunjukan bahwa capaian kinerja pada aspek-aspek tertentu masih relatif rendah. Aspek Kinerja yang relaif masih rendah dan perlu dilakukan peningkatan adalah pendekatan pada tokoh Formal. Peneliti mendalami kondisi ini dengan obsevasi dimana diketahui bahwa penyuluh KB masih merasa canggung dan sulit untu membina hubungan dengan tokoh formal seperti camat karena interaksi yang jarang terjadi. Capaian yang relatif rendah juga ditunjukan oleh aspek inovasi. Berdasarkan capaian pada tabel ditunjukan bahwa Penyuluh KB kota Palembang dan Prabumulih relatif masih rendah alam melakukan Inovasi pada media Komunikasi Informasi dan Edukasi (KIE), pada proses advokasi dan KIE dan pada proses pembinaan. Penyuluh KB kota palembang dan Prabumulih memiliki kecepatan kerja yang relatif rendah karena penyelesaian pekerjaan sering kali tidak sesuai dengan jadwal yang telah ditetapkan. Dalam aspek keakuratan kerja Penyuluh KB kota Palembang dan prabumulih juga memiliki capaian yang relatif rendah karena proses kerja dilakukan tanpa emmperhatikan data basis. Penyuluh KB kota Palembang dan Prabumulih berdasarkan data belum mampu melakukan analisis data sehingga kekauratan kerja masih relatif rendah. Namun secara keseluruhan, kinerja Penyuluh KB berada dalam kondisi baik.

\section{Pengaruh Lingkungan Sosial terhadap Kinerja Penyuluh KB}

Pengaruh lingkungan sosial terhadap kinerja Penyuluh KB kota palembang dan prabumulih diukur dengan melakukan uji regresi linier sebagai berikut :

Tabel 3. Coefficients ${ }^{a}$

\begin{tabular}{cccccc}
\hline & \multicolumn{3}{c}{ Unstandardized Coefficients } & Standardized Coefficients & \\
\cline { 2 - 5 } Model & $\mathrm{B}$ & Std. Error & Beta & t & Sig. \\
\hline
\end{tabular}




\begin{tabular}{rrrr}
\hline 1 & 6,303 & 9,566 & $, 659,515$ \\
\hline Lingkungan sosial & 1,268 &, 135 & $, 871 \quad 9,379,000$ \\
\hline
\end{tabular}

a. Dependent Variable: Kinerja Penyuluh KB

Nilai koefesien regresi untuk variabel lingkungan sosial berdasarkan tabel diatas adalah sebesar 1,268 sementara tingkat nilai Sig. sebesar 0,000 atau dengan kata lain diketahui bahwa Sig. $<\alpha=0,05$, sehingga dapat dinyatakan bahwa variabel lingkungan sosial memiliki pengaruh positif dan signifikan terhadap kinerja penyuluh KB Kota Palembang dan Kota Prabumulih. Dari tabel hasil uji linier sederhana tersebut diperoleh model regresi oinier yaitu $Y=6,303+1,268 \mathrm{x}$ (Lingkungan sosial. Dari persamaan ini dapat diterjemahkan bahwa konstanta sebesar 6,303 adalah nilai kinerja Penyuluh KB tanpa adanya nilai variabel lingkungan sosial dalam penelitian ini, sedangkan nilai koefesien regresi variabel lingkungan sosial sebesar 1,268 dan bernilai positif. Hal ini dapat diartikan jika setiap penambahan 1 satuan niali koefesien variabel lingkungan kerja, maka kinerja Penyuluh KB akan bertambah sebanyak 1,268 satuan.

Untuk mempermudah melihat besaran pengaruh lingkungan sosial terhadap kinerja maka, maka dilakukan analisis lanjutan dengan menggunakan metode R Squere. Berikut ini adalah hasil pengolahannya

Tabel 4. Model Summary ${ }^{b}$

\begin{tabular}{|c|c|c|c|c|}
\hline Model & $\mathrm{R}$ & R Square & Adjusted R Square & Std. Error of the Estimate \\
\hline 1 &, $871^{a}$ & 759 & 750 & 5,262 \\
\hline \multicolumn{5}{|c|}{ a. Predictors: (Constant), Xi } \\
\hline \multicolumn{5}{|c|}{ b. Dependent Variable: Yi } \\
\hline
\end{tabular}

Dari tabel 4, dapat diketahui dari kolom Adjusted R Square bahwa pengaruh variabel lingkungan sosial terhadap kinerja adalah sebesar $75 \%$, lebih dari itu, variabel kinerja penyuluh KB dipengaruhi oleh variabel lain yang tidak diteliti di penelitian ini.

Ainswort et al (2002) mengatakan bahwa keberasilan sebuah pekerjaan bergantung pada penciptaan lingkungan manusia yang tepat dengan memperhatikan keterampilan komunikasi. Dalam pekrjaannya sebagai penyuluh KB hubungan sosial antar manusia yang membentuk lingkungan sosial memberikan dampak kepada keberhasilan Penyuluh KB menjalankan tugas dan fungsinya. Dukungan dari masyarakat sebagai sasaran atau mitra kerja akan menambah kualitas dan kuantitas pekerjaan.

Penelitian ini sejalan dengan penelitian sebelumnya yaitu penelitian Latief \& Rosalina (2019), yang mengatakan bahwa semakin baik hubungan manusia dalam pekerjaan akan berdampak baik pada peningkatan kinerja. Holid \& Meilani (2018), juga mengatakan bahwa Lingkungan kerja sosial memiliki pengaruh positif dan signifikan tehadap kinerja karyawan, karenanya hubungan antara karyawan perlu diperhatikan dan ditingkatkan.

\section{SIMPULAN}

Berdasarkan analisis data dan pembahasan mengenai pengaruh lingkungan sosial terhadap kinerja Penyuluh KB Kota Palembang dan Kota Prabumulih diperoleh kesimpulan bhawa lingkungan sosial dan kinerja Penyuluh KB kota palembang dan prabumulih dalam keadaan baik. Pengaruh lingkungan sosial terhadap Kinerja Penyuluh KB kota palembang dan Prabumulih berpengaruh positif dan signifikan. Hal ini menunjukan bahwa semakin baik lingkungan sosial yang merupakan hubungan antara Penyuluh KB dengan masyarakat sebagai sasaran program dan masyarakat sebagai Mitra kerja maka akan berdampak pada peningkatan kinerja Penyuluh KB Kota Palembang dan Kota Prabumulih. 


\section{DAFTAR PUSTAKA}

Ainsworth, W. M., Smith, N., \& Millership, A. (2002). Managing performance, managing people: understanding and improving team performance. Longman Publishing Group.

Budianto, A. A. T., \& Katini, A. (2017). Pengaruh lingkungan kerja terhadap kinerja pegawai pada PT Perusahaan Gas Negara (PERSERO) Tbk SBU Distribusi wilayah I Jakarta. KREATIF: Jurnal Ilmiah Prodi Manajemen Universitas Pamulang, 3(1).

Chandrasekar, K. (2011). Workplace environment and its impact on organisational performance in public sector organisations. International Journal of Enterprise Computing and Business Systems, 1(1), 1-19.

Cohen, et al. (2007). Research Method in Education (6 th ed). Routlodge Falmer.

Darmanto, R. S. (2016). Pengaruh Kompetensi, Motivasi Dan Lingkungan Kerja Terhadap Kinerja Penyuluh Lapangan Program Keluarga Berencana (PLKB) Di Kabupaten Pemalang. Media Ekonomi Dan Manajemen, 29(1), 68-82.

Doane, D., Awasinombu, A. H., \& Putera, A. (n.d.). Pengaruh Pendidikan, Pelatihan Dan Lingkungan Kerja Terhadap Kinerja Penyuluh Keluarga Berencana. Jurnal Manajemen, Bisnis Dan Organisasi (JUMBO), 3(2), 195-207.

Dolonseda, H. P., \& Watung, S. R. (2020). Dampak Lingkungan Kerja dan Etos Kerja Terhadap Kinerja Pegawai. PUBLIC POLICY (Jurnal Aplikasi Kebijakan Publik \& Bisnis), 1(2), 288-297.

Fatchiya, A., Sulistyawati, A., Setiawan, B., \& Damanik, R. (2021). Peran Penyuluhan Keluarga Berencana dalam Meningkatkan Pengetahuan KB pada Pasangan Usia Subur (PUS) Kelompok Masyarakat Miskin. Jurnal Penyuluhan, 17(1), 60-72.

Hamid, N. Z. A., \& Hassan, N. (2015). The relationship between workplace environment and job performance in selected government offices in Shah Alam, Selangor. International Review of Management and Business Research, 4(3), 845-851.

Harsuko, R. (2011). Mendongkrak Motivasi dan Kinerja: Pendekatan Pemberdayaan SDM. Universitas Brawijaya, Malang.

Holid, A., \& Meilani, R. I. (2018). Pengaruh lingkungan kerja sosial terhadap kinerja karyawan direktorat akademik di sebuah perguruan tinggi di Indonesia. Jurnal Pendidikan Manajemen Perkantoran (JPManper), 3(1), 54-62.

Latief, A., \& Rosalina, D. (2019). Analisis Hubungan Antar Manusia terhadap Kinerja Karyawan. Journal of Education, Humaniora and Social Sciences (JEHSS), 1(3).

Lestary, L., \& Chaniago, H. (2017). Pengaruh Lingkungan Kerja Terhadap Kinerja Karyawan. Jurnal Riset Bisnis Dan Investasi, 3(2), 94-103.

Mangkunegara, A. A. A. P. (2016). Manajemen sumber daya manusia perusahaan. PT. Remaja Rosdakarya.

Nitisemito, A. S. (2002). Manajemen Personalia Edisi Revisi. Jakarta: Ghalia Indonesia.

Puspita, D. R. (2011). Pengaruh Motivasi Kompetensi dan Lingkungan Kerja pada Kinerja Aparatur Penyuluh Keluarga Berencana. JIANA (Jurnal Ilmu Administrasi Negara), 11(01), 87-96.

Rusmiah, R., Brasit, N., \& Mardiana, R. (2019). Pengaruh Karakteristik Individu, Kompetensi, Dan Lingkungan Kerja Terhadap Kinerja Penyuluhan Keluarga Berencana Kabupaten Mamuju Provinsi Sulawesi Barat. Hasanuddin Journal of Applied Business and Entrepreneurship, 2(4), 98-107.

Sedarmayanti, S. D. M., \& Kerja, P. (2009). Cetakan Ketiga, Bandung, CV. Mandar Maju.

Singarimbun, M. (1995). Metode Penelitian Survey, Jakarta : LP3ES

Syafruddin, S., Hariadi, S. S., \& Wastutiningsih, S. P. (2014). Tingkat Kinerja Penyuluh Pertanian di Kabupaten Konawe Provinsi Sulawesi Tenggara. Jurnal Penyuluhan, 10(2), 183-196.

Timpe, A. D. (1992). Seri Ilmu dan Seni Manajemen Bisnis “Kinerja.” Jakarta: Elex Media Komputindo.

Yuniati, T. (2016). Pengaruh Karakteristik Individu, Pekerjaan, Dan Lingkungan Kerja Terhadap Kinerja Karyawan. Jurnal Ilmu Dan Riset Manajemen (JIRM), 5(8), 1-18. 